\title{
Presence, Place, Period, and Principle: A Medievalist's Reflections on Robert Bartlett's Book about Saints
}

\section{RICHARD KIECKHEFER}

$\mathrm{T}$ HE title of Robert Bartlett's book on saints, Why Can the Dead Do Such Great Things?, comes from Saint Augustine, who thought of heaven as a preeminently social environment. It is thus easy to entertain a fantasy about a conversation among saints in heaven. One saint boasts that his feast day has a higher liturgical ranking than the others'. This provokes a second saint to point out that the first may have a grand feast day, but is not, like himself, the subject of a properly papal canonization. A third saint is proud of his artistic representations. A fourth points out that he is so important that he is mentioned in Robert Bartlett's latest book. But this boast backfires. All the saints burst into laughter. As one of them points out, "That's nothing special-we're all in Bartlett's book! He didn't miss any of us!"

Compendious as Bartlett's book is, it is a storehouse not only of information, but of insightful reflections. These sometimes come unexpectedly, as when Bartlett notes how the international cult of Brigid was far greater than that of Patrick, which demonstrates that "there is no relation between the historical reality of a saint and the importance of their cult." ${ }^{, 14}$ Or, when in discussing Gregory the Great, he notes in passing how Gregory shows the networking that could occur among saints: the great sainted pope received a letter from Saint Columbanus (a disciple of Saint Columba), he was proudly attentive to the relics of earlier saints in Rome, and he aroused the interest of Saint Gregory of Tours (himself a hagiographer as well as a saint). ${ }^{15}$ The communion of saints emerges as a complex network of saints and their various categories of associates.

A book as sweeping as this will inevitably lead different readers to focus on different themes, perhaps those which correspond most closely to their own interests. Four aspects of the book come especially to my attention.

The first is a recurrent theme in Bartlett's book, most fully developed in the concluding chapter: the problematic notion of the saints' presence. God is, of course, assumed to be ubiquitous, and the angels and demons have local

\footnotetext{
${ }^{14}$ Bartlett, Why Can the Dead Do Such Great Things?, 33.

${ }^{15}$ Ibid., 44.
}

Richard Kieckhefer is Sarah Rebecca Roland Professor of Religious Studies at Northwestern University. 
presence, but dart about quickly as messengers of their celestial and infernal majesties. What about the saints? In principle one can make a threefold distinction: their souls are present in heaven (and they do not normally come back to earth), their bodies are present on earth as relics (whether whole or fragmented), and their effects are so widely experienced that one can speak of them as virtually, if not literally, ubiquitous. But, as Bartlett makes clear, this tidy trichotomy corresponds only roughly to actual medieval belief and practice. A devotee of Saint Eutropius could be mocked for invoking him constantly, even far from his tomb: ${ }^{16}$ it was at the tomb that the saint was effectively present, and the third member of the trichotomy I have sketched was here folded into the second. One should not be surprised to find conflict between two notions of the afterlife: the official notion that souls go to heaven, purgatory, or hell, and the unofficial, but widespread, belief that souls linger at the tomb. It is more surprising to find this confusion in the case of the saints. Perhaps the confusion was inevitable, because the mechanism by which the saint's efficacy as an intercessor and posthumous miracle-worker was so vaguely defined and articulated.

The case of Christ was relatively straightforward: he had lived on earth at a particular time and place, but the same person who had that human life in history was also divine, and thus ubiquitous, available at any time to hear and answer prayer. His Mother did not have any theological claim to ubiquity, and in principle her body was already in heaven, and her accessibility on earth was less obviously defensible, but in practice, she was invoked as if she were just as ubiquitous as her Son. The rest of the saints were more manifestly problematic. One could pray to them, but how exactly was the prayer transmitted to them? Did it go through God, as through a kind of celestial switching board? Were their souls in heaven possessed of such remarkably keen hearing that they could hear prayers beamed at them from the living on earth? Did they hear even petitions that were mental and not voiced? As Bartlett points out, Augustine thought of interaction between the living and the dead as not natural but marvelous, ${ }^{17}$ which suggests that there was something extraordinary, if not miraculous, about the capacity of the saints to hear prayers for their intercession. There was never any clear and widely shared answer to these questions, and thus the faithful were left to imagine any of various mechanisms.

In late antiquity the dead were often seen as present to their physical remains or their place of burial. For Egyptians, the $b a$ (roughly the soul) might go to the underworld, yet return and hover about the mummified corpse, while the $k a$ (character) and $a k h$ (a kind of efficacious light) remained linked to the tomb

\footnotetext{
${ }^{16}$ Ibid., 105.

${ }^{17}$ Ibid., 104.
} 
and to tomb offerings. ${ }^{18}$ When the Romans severed a bone before cremation, the os resectum stood symbolically for, and thus preserved, the entire body and served as a medium of presence. In early Judaism, Mira Balberg has argued convincingly, the key question was how far the physical remains were of such quality and quantity as to stand effectively for the entire living person; if they were, they sufficed to pollute. Christian conceptions of the dead and their lingering presence, chiefly in relics, were not necessarily less complex, but tended to be smoothed over in official theological reflection.

Precisely how Christian saints' relics mediated presence remains a complex question. The most important classical pilgrimage sites-Rome, Santiago de Compostela, Canterbury-were places that claimed to possess whole or nearly whole bodies. Canterbury dispensed highly diluted portions of the saint's blood, while Gregory the Great famously resisted fragmenting apostolic bones. ${ }^{19}$ In all three cases, the logic of part equaling whole is counterbalanced by the unique status and magnetic allure of sites that possessed integral remains. For Theofrid of Echternach, however, bodily integrity was not an issue: he celebrated the sanctity not simply of the saints' fragmented bodies, but of their bodies fully disintegrated into powdery dust. The sacred dignity of the saints is so abundantly conveyed by that dust that this apparently worthless matter is what adorns the precious metal and gems of the reliquary, not the other way around. The glorified spirit glorifies the flesh, however much it is decayed, however little it remains recognizable. ${ }^{20}$ Theofrid did not know about "speaking" or body-part reliquaries, but if he had been able to foresee them, he would not have required them for his view of relics. Relics were sacred and powerful, yet they did not mediate personal presence so forcefully as the saints' names, which could be invoked not just locally, but universally. Relics pass piecemeal from place to place and present themselves to the outer eyes, but the names pass whole and entire, reaching the inner senses. The bodies may be far away, but the names are present to the faith of those who invoke them (Vbique sunt fidei presentia, cum corpora longe sint absentia). Wherever invoked, they make the absent saint present. ${ }^{21}$

Liturgy was also a mediation of presence, most fundamentally of Christ, but also of the saints whose feasts were celebrated. In principle, the commemorations were addressed to God, acknowledging the grace he had

\footnotetext{
${ }^{18}$ Donald B. Redford, ed., The Oxford Encyclopedia of Ancient Egypt (Oxford: Oxford University Press, 2001), 1:47-48, 1:161-162, 2:215-217.

${ }^{19}$ The Letters of Gregory the Great, trans. John R.C. Martyn (Toronto: Pontifical Institute of Mediaeval Studies, 2004), 310-311.

${ }^{20}$ Theofridus Abbas Epternacensis, Flores epytaphii sanctorum, ed. Michele Camillo Ferrari (Turnhout: Brepols, 1996), bk. 1, ch. 2 (esp. p. 12); bk. 2, chs. 2-3 (esp. pp. 35-37).

${ }^{21}$ Ibid., bk. 3, ch. 1, esp. pp. 59-61.
} 
bestowed upon the saints, who remained before the divine throne. But the saints could also be imaged as coming down to join in the celebration. According to Mechthild of Magdeburg, "When one honors the saints by remembering them well, ... as one can do on the day that God honored them with a holy death, they are so grateful that they immediately come in all the glory that they received from their holy actions." Mechthild goes on to tell of seeing Mary Magdalene dancing in the choir and gazing into the eyes of the nuns as they chanted. $^{22}$

In short, the simple schema that places the soul of the saint in heaven, locates the body of the saint in the tomb, and finds the efficacy of the saint ubiquitous is complicated. Potentially rival conceptions are not fully integrated. And Bartlett's book affords an excellent starting point for exploring this complexity.

A second theme that I want to single out and pursue is that of localism in the cult of saints. Even more than the saints' presence, this is a recurrent theme in Bartlett's book. He tells us that the cult of saints was largely a local phenomenon, ${ }^{23}$ that ranking of saints' liturgical feasts was a local matter, ${ }^{24}$ that there were widely shared saints inherited from earlier centuries yet the cult of newer saints represented "a strong countercurrent of localism,",25 that a case for canonization brought to the curia by a powerful lobby would not be representative of local notions of sanctity, ${ }^{26}$ that the civic patriotism of later medieval Italy gives a clear example of local particularity, ${ }^{27}$ that on a local level strikingly unofficial cults could arise such as that of the greyhound Guinefort, ${ }^{28}$ and that reverence could be particularly keen for local saints whose tombs were near at hand. ${ }^{29}$ What drew my attention most strongly was the observation that in the thirteenth century, the ratio between canonized and uncanonized saints was roughly $1: 21,{ }^{30}$ which raises the question whether the canonized few were in a sense epiphenomenal, and the uncanonized, many whose cult was and sometimes remained active locally, represent the real core of later medieval hagiolatry.

Indeed, much of the religion of medieval Europe was cultivated below our radar. Historians of late medieval Germany (to consider just one country) are of course aware of Wilsnack, Altötting, and other widely publicized sites where the attractions were controversial or the record-keeping particularly

\footnotetext{
${ }^{22}$ Mechthild of Magdeburg, The Flowing Light of the Godhead, trans. Frank Tobin (New York: Paulist, 1998), bk. 6, ch. 9, p. 235.

${ }^{23}$ Bartlett, Why Can the Dead Do Such Great Things?, 126.

${ }^{24}$ Ibid., 120.

${ }^{25}$ Ibid., 130

${ }^{26}$ Ibid., 142.

${ }^{27}$ Ibid., 143 .

${ }^{28}$ Ibid., 185 .

${ }^{29}$ Ibid., 220.

${ }^{30}$ Ibid., 64.
} 
efficient, or sites such as the Jakobskirche in Rothenburg ob der Tauber where shortly before the Reformation a relic of Christ's blood was given a monumental altar shrine carved by Tilman Riemenschneider. But for some years I have been telling students that if you printed out a map of Germany on an $81 / 2$ by 11 inch sheet, with a red dot everywhere there was a pilgrimage site, it would be all red. If one goes down into the valley below Rothenburg, one finds the Kobolzell church, which was also the focus of a Marian pilgrimage, known mainly from circumstantial evidence of donations, furnishings, and facilities for circulation. ${ }^{31}$ And a few kilometers from Rothenburg lay Creglingen, where a wonder-working host was discovered in a field in $1334 .^{32}$ That there was a pilgrimage dedicated to St Nicholas at Geiß-Nidda in Hessen is again known from indirect evidence: a woman from Bleichenbach went there in 1226 seeking relief from lameness, and she was partially healed, but a full cure came only six years later when she visited the grave of Saint Elizabeth in Marburg. ${ }^{33}$ It is the oneupmanship and efficient record-keeping of the shrine-keepers at Marburg that tell us of the lesser pilgrimage. Marburg, unlike Geiß-Nidda, was at the tip of the iceberg.

Bartlett's observations about localism, along with other such evidence, lead to the profoundly important issue of how local religion in the medieval West related to broader, centralizing and universalizing impulses. William Christian has emphasized how local sites can become co-opted and transformed when hierarchical authority moves in and takes charge. ${ }^{34}$ When a site is regularized and brought in line with official norms, relics or some other sacred objects may be translated to a church where they are more generally accessible and access is more tightly controlled. But something is lost in the translation: the link between the sacred object and the original site, which may point to chthonic or otherwise "natural" associations of the cult. Canonization itself is the most obvious case of a double-edged process: the effect is aggrandizement of central authority, but the initiative, more often than not, comes from the local community seeking broader recognition of a hometown favorite, and willingly submitting to the regimentation that such recognition implies.

\footnotetext{
${ }^{31}$ Anton Ress, Stadt Rothenburg o.d.T.: Kirchliche Bauten (Munich: Oldenbourg, 1959); Karl Borchardt, Die geistlichen Institutionen in der Reichsstadt Rothenburg ob der Tauber und dem zugehörigen Landgebiet von den Anfängen bis zur Reformation (Neustadt/Aisch: Degener, 1988).

${ }^{32}$ Sabine Kutterolf-Ammon, Die Herrgottskirche zu Creglingen, 4th ed. (Gerchsheim: Kunstschätzverlag, 2012).

${ }^{33}$ Peter Fleck and Dieter Wolf, ed., Katholisches Leben in Butzbach in Mittelalter und Neuzeit: Festschrift zur 100-Jahrfeier der Katholischen Pfarrgemeinde Butzbach (Butzbach: im Auftrag der katholischen Pfarrgemeinde St. Gottfried, 1994), 55.

${ }^{34}$ William A. Christian, Jr., Apparitions in Late Medieval and Renaissance Spain (Princeton, N.J.: Princeton University Press, 1981).
} 
It was in his work on sainthood in late antiquity that Peter Brown warned against naive distinction between elite and popular culture-and historians have taken up his warning, perhaps at times bending over so far as to avoid popular-elite distinctions even when they are valid and useful. ${ }^{35}$ One related distinction that becomes increasingly important in the last medieval centuries is that between local religion (which is likely to engage and reflect the social hierarchies rooted in the community) and translocal religion (which in the later medieval West increasingly comes under the influence of centralized ecclesiastical institutions such as the episcopacy, papacy, and religious orders). An important set of questions arises out of that distinction. What factors enter into the negotiation that give local characters and sites translocal significance? How far and in what ways do the centralizing effects of hierarchical authority, the generalizing tendencies of the mendicant orders, and the conformism of mimesis encounter local resistance? When communities seek to establish their special importance, can they do so in ways that are not largely borrowed from elsewhere: does distinction require conformity?

The legends and cult of saints provide one of the best opportunities for exploring these issues, not only because the process underwent a general transition from more local and unofficial to more centralized and official control, but because in every case that went before central authority the ontogeny of the particular cult recapitulated the phylogeny of saint-making. The records of canonization often give evidence for the transition from incipient recognition (explored, for example, by Aviad Kleinberg) to local veneration and then to centrally sanctioned cult. ${ }^{36}$ One might write a history as long as Bartlett's of those saints who got left behind or remained important only locally, and that history would show change over time, from an age when there was less concern with the distinction, to one in which there were clear boundaries between the canonized saint with, in principle, universal cult; the blessed with local cult; and the losers such as Thomas of Lancasters whose cults were officially disallowed. The history would also be an exercise in the importance of record-keeping as both the effect and the cause of broader recognition.

My third theme is a much broader one: chronology. Part I of Bartlett's book is chronological, and in two key passages he gives important chronological distinctions. He speaks of three eras distinguished for the production of many saints: the early era of persecution, the sixth and seventh centuries,

\footnotetext{
${ }^{35}$ Peter Brown, The Cult of the Saints: Its Rise and Function in Latin Christianity (Chicago: University of Chicago Press, 1981).

${ }^{36}$ Aviad Kleinberg, Prophets in Their Own Country: Living Saints and the Making of Sainthood in the Later Middle Ages (Chicago: University of Chicago Press, 1992).
} 
and (particularly in Italy) the late Middle Ages. ${ }^{37}$ Then he speaks of the history of papal canonization as falling into three phases: the time before 993 when there is no reliable evidence of such canonization, roughly two centuries when there were 38 papal canonizations but no claim that popes alone could canonize, and the period after Alexander III when canonization was a papal prerogative. After page 91, however, the book is more thematic than chronological, and development over time is not its main concern. Rather, material from early and late medieval centuries is entered side-by-side as evidence for the longue durée of medieval sainthood. This is not a criticism, merely an observation. Still, it could be useful to examine chronological patterns in more detail and to ask what aspects of sainthood did most lend themselves to change over time.

Let me make a few remarks, focusing on the period of my own research, the late Middle Ages. Bartlett notes that this was a time when lay involvement in devotion to saints was on the rise, even apart from the increasing tendency for people to be named for saints: "Participation in confraternities and attendance at a saint play were ways in which lay people could become more actively involved in the cult of the saints, and this lay involvement intensified over the course of the later medieval period," with the aid of wood-block prints and vernacular literature. ${ }^{38}$ In my copy of Bartlett's book, I have made marginal notation of all the passages in which he discusses late medieval material, and they abound. More might be said, however, about tendencies that are particularly characteristic of the period.

Saints in the late medieval West were thought of and represented more than before in associative clusters. The Fourteen Helpers are the most obvious and perhaps most important example: fourteen saints who are not linked by historical connection, but were seen as having such pronounced analogous intercessory function that they became a class unto themselves. ${ }^{39}$ Much the same happened to the legendary or semilegendary virgin martyrs who were so important in hagiographic retelling and in personal nomenclature in the late medieval West: Catherine, Barbara, Margaret, Christina, and a few others, who came to be represented together in art as if they belonged to a new Holy Kinship. ${ }^{40}$ And of course the original Holy Kinship would be another example of what I am referring to, except that they do have

\footnotetext{
${ }^{37}$ Bartlett, Why Can the Dead Do Such Great Things?, 145.

${ }^{38}$ Ibid., 81 .

${ }^{39}$ Reinhard Abeln, Die Vierzehn Nothelfer: Ihr Leben und ihre Verehrung (Kevelaer: Lahn, 2013).

${ }^{40}$ Karen A. Winstead, The Virgin Martyrs: Legends of Sainthood in Late Medieval England (Ithaca, N.Y.: Cornell University Press, 1997); Osbern Bokenham, A Legend of Holy Women: A Translation of Osbern Bokenham's Legends of Holy Women, trans. Sheila Delany (Notre Dame, Ind.: University of Notre Dame Press, 1992).
} 
historical connection among themselves. Even the Doctors of the Church, who had previously been linked as authorities, took on greater devotional significance. On a smaller scale there were pairings of saints brought into association, perhaps because they were somehow complementary. The plague saints Sebastian and Roch are paired as antiquus and modernus, as martyr and confessor, as metaphorical and literal victim of plague. ${ }^{41}$ Perhaps this associative impulse is related to the rise in prominence of voluntary associations of various sorts, particularly confraternities, which themselves could be dedicated to saints. Living Christians who sought more than the required religion of the parish were gathering in associations in which they exercised supererogatory piety, and at the same time they became fond of seeing the saints as gathering in hagiographic associations. Or perhaps, rather, on the broadest level, we can say that an era of burgeoning supererogatory devotionalism required some kind of conventional structure, and both the associations of living Christians and the bonds ascribed to their patrons helped to make sense of what might otherwise have been a chaotic devotional jungle.

If saints were often assigned to hagiographic clusters, northern Europe in the late medieval also saw a kind of collective hagiography become popular, in the form of the sister books that represented multiple members of a convent as saintly individuals and thus testified to the venerability of the community, particularly in its formative years. The genre is not entirely novel: Bartlett refers to the serial biography found much earlier, especially at Ravenna. ${ }^{42}$ Parallels can be found in other religions, especially Islam. In the late medieval West, it seems to me the tendency has something to do with the kind of reform being promoted in women's monasteries, but something also to do with a widespread concern to acknowledge the manifold presence of the sacred in people's lives without reinforcing too much a quest for singularity. The singular individual could always be both a blessing and a problem within a community, and the collective accounts of holiness sought a balance between recognition of the exceptional and subordination to the communal.

The late medieval West also saw new options, however, in the representation of women's mystical piety. Bartlett sprinkles a bit of cold water on Vauchez's notion of the "feminization of lay sainthood"; ${ }^{43}$ numerically the women were

\footnotetext{
${ }^{41}$ Heinrich Dormeier, "Saints as protectors against plague: problems of definition and economic and social implications," in Living with the Black Death, eds. Lars Bisgaard and Leif Søndergaard (Odense: University Press of Southern Denmark, 2009), 161-186; Neithard Bulst, "Heiligenverehrung in Pestzeiten: sociale und religiöse Reaktionen auf die spätmittelalterlichen Pestepidemien," in Mundus im imagine: Bildersprache und Lebenswelten im Mittelalter, eds. Andrea Löther, et al. (Munich: Fink, 1996), 63-97.

${ }^{42}$ Bartlett, Why Can the Dead Do Such Great Things?, 188.

${ }^{43}$ Ibid., 146.
} 
not as well represented as we might like to suppose. But there were important developments in the ways women could be represented: a more pronounced fusion of hagiography with theo-erotic mysticism, with emphasis on the link between illness and spiritual advancement, on the passivity before an active Bridegroom, on a full range of mystical encounters. Women's vitae in the late Middle Ages tended to be far longer than men's, because they were given to such full exploration of not just public virtue but inner grace and turmoil. They were also far longer than most classical hagiography. The vitae of Saint Anthony and Saint Martin were tremendously influential, but in terms of length, they fall far short of some late medieval women's vitae. The woman saint was in effect a kind of crystalline monstrance: reading her vita, one could see through to the innermost core of her saintly being. This is, I think, among the most important developments of the period, and it shows one of the ways sainthood can change over time.

The fourth theme that I want to highlight and develop is the theological assumptions behind sainthood, both for theologians and for more ordinary believers. This is a matter that Bartlett discusses most explicitly in his chapter on what happened to sainthood and the saints in the Protestant Reformation, when the institution came under challenge. Most fundamentally, sainthood in the West rests on two theological foundations: the notion of supererogation and the idea of the communion of saints. In terms of practical import, supererogation was perhaps the most basic point of contestation between Catholics and Protestants. It underlay the theory of indulgences, it was the motive for asceticism and thus for monasticism, and it was the key to the notion of saints whose heroic virtue merited special reward, all of which came under fire in the sixteenth century. It was also fundamental to Anselmian soteriology, which was not so problematic, because Christ's work of supererogation more easily than human supererogation could be accommodated in a Protestant theology. What was not said in the theology of sainthood, but arguably was implied by practice, was that in a sense the supererogation was reciprocal. The saints gained their status and their intercessory power by their supererogatory virtue, and living faithful gained favor with the saints by showing them special devotion that was not strictly required. The devotee was assimilated to the status of the saints to that degree: they were bound together by a sense of belonging to a religion that required much of them, but also allowed the option of gaining special status and special favor by doing yet more.

As for the communion of saints, this was a traditional way of formulating a point made recently by Robert Orsi, that what is most fundamental to religion is the network of relationships it allows and promotes-relationships among the living, to be sure, but also between the living and the dead, usually beneficent 
and beneficial, but at times dysfunctional. ${ }^{44}$ We pray for the souls in purgatory, and we pray to the saints in heaven for their intercession, not because we seek to enter into a relationship with them, but because we are already bound together within the same communion, and as members of that communion we have bonds of fidelity and also of responsibility that balance the favor we anticipate.

The language of supererogation and communion of saints was, of course, theological language spoken by the learned. But the concepts could easily be grasped by any reasonably devout Christian, who would have understood in her bones that doing extra was a key to favor and power, and that religion involved a network of relationships that entailed mutual respect and attention. Bartlett's book deals somewhat with these links between theology and ordinary religious practice; if he were willing to add another hundred or so more pages to an already magnum opus, developing this theme too would be a fitting act of supererogation.

\footnotetext{
${ }^{44}$ Robert Orsi, Between Heaven and Earth: The Religious Worlds People Make and the Scholars Who Study Them (Princeton, N.J.: Princeton University Press, 2004), 2-3.
} 